\title{
徳島市に蚊の天敵として移殖した カダヤシに関する観察*
}

佐藤 英毅 1,2$)$ 大久保新也1）佐々 学2) 和田芳武2）元木貢2）田中寬2)

山岸宏3）沖野外輝夫4) 栗原毅5)

1）徳島市防蚊対策研究室（徳島市幸町）

2）東京大学医科学研究所寄生虫研究部（東京都港区白金台）

3）帝京大学医学部動物学教室（分王子市大塚）

4）野村総合研究所（鎌倉市梶原）

5）帝京大学医学部医動物学教室（東京都板橋区加賀）

（受領：1972 年 7 月 12 日）

Observations on Gambusia affinis introduced into Tokushima as a natural enemy of mosquitoes*

Hideki SATo, ${ }^{1,2)}$ Shinya OkUbo, ${ }^{1:}$ Manabu SAsA, ${ }^{2)}$ Yoshitake WAdA, ${ }^{2)}$ Mitsugu Motoki, ${ }^{2}$ Hiroshi TANAKA, ${ }^{2}$ Hiroshi YamagishI, ${ }^{3}$

Tokio OKINO ${ }^{4}$ and Takeshi KURIHARA ${ }^{5}$

1)Laboratory for Mosquito Control, Saiz'ai-cho, Tokushima

${ }^{2}$ Department of Parasitology, Institute of Medical Science, L'niversity of

Tokyo, Shiroganedai, Minato-ku, Tokyo

3) Department of Zoology, Faculty of Medicine, Teikyo University, Hachioji, Tokyo

4) Nomura Research Institute, Kamakura, Kanagarea

5) Department of Medical Zoology, Faculty of Medicine, Teikyo Unizersity, Itabashi-ku, Tokyo

\section{I.はじめに}

德島市は四国東部，吉野川の河口付近にあるデルタ地 帯に発達した現在人口約23万の都市で，土地が低く，下 水などの排水が困難で水溜りが多く，かつ周囲が低湿地 帯で囲まれているため昔から蚊の発生がきわめて多くて 日本脱炎の発生も高率であった。ここで徳島市および医 師会が協同して 同市医師会館内に 1969 年から防蚊対策 研究室を作り，これに東大医科研寄生虫研究部が協力し て蚊の調查および対策の研究を行ならことになり，とく に蚊幼虫の天敵としてのカダヤシ Gambusia affinis の 利用を重点に作業をすすめた。この報告は 1968 年秋か ら 3 年あまりにわたる期間にあげられた成果のあらまし をまとめたものである。なおこの成績の概要は佐藤らに

*この研究は文部省科学研究費（胎生メダ力班）の禣 助を受けた。
より 1970 年度から毎年の日本衛生動物学会に報告され。 その要旨が臥刷されている.

この調查研究計画は 1968 年 10 月に大久保が徳島市医 師会長として防蚊研究室設置にともなう打合せに東大医 科研を訪れたときにはじまり，その後佐々，佐藤が 1969 年 4 月 2 日上り同市に赴いて蚊発生源などの調查を行な い，佐藤はひきつゔき滞在して諸研究作業を担当し今日 におよんでいる。同年 5 月 21 日より 1 週間, 和田が出 張して蚊の調查, ライトラップの運転開始に協力し, さ らに和田, 元木が 7 月 16 日より 8 月 29 日の間, 佐藤お よび市衛生部担当者と協同で広範な調查を行なった。 た, 1971 年 10 月 23 日より 26 日の間, 山岸, 沖野, 栗 原, 和田が参加して主としてカダヤシの密度調査を行な った。 またここの報告は主として佐々が 1972 年 4 月 7 日より 10 日にかけて徳島に滞在し，それまでの 3 年間 に佐藤らにより集積された資料をとりまとめ，また山岸 
が生息密度に関する調查をまとめて完成したものであ る.

カダヤシ（トップミノウ）Gambusia affinis (Baird et Girard, 1853) は北米南部に 原産する胎生メダカ科 Poeciliidaeの淡水魚で，主としてマラリア媒介蚊駆除の 目的で今世紀初めころより世界各地に移出され，その成 果については多くの報告があって, Gerberich and Laird (1966)がくわしく紹介している，日本に移入された経過 については，中村守純（1941）の記録によると，1905 年にスタンフォード大学のアルビンシール氏がテキサ ス州から ハワイに 405 尾を送ってそのうち 378 尾が健 全に到着し，八ワイ各島で繁殖に成功したものをさら に 1911 年に台湾総督府の井街技師が船便で 500 尾を横 浜経由で台湾に送り，うち 124 尾が健全で到着し，同 地で繁殖したものを 1916 年に奈良県郡山の 金魚商小松 春鱗氏が約 200 尾輸入して滋賀，和歌山両県下で繁殖さ せたという。これについては岡田（1957)，佐々(1967， 71，72）などの解説もあり， 八ワイの現況については Nakagawa and Ikeda (1969) がくわしく報告してい る.

ところで，戦後になっておそらくその子孫と考えられ るカダヤシが東京周辺の污水域にひろく繁殖しているこ とが注目され，マラリア媒介蚊駆除の目的よりも，むし ろ下水に発生しフィラリア病を媒介するアカイエカの駆 除に有効なことが注目されるにいたった（佐タ，1970， 71，72）。徳島市に 移植したカダヤシは後述するように 1969 年の 4 月と 5 月の 2 回にわたって 羽田空港の排水 溝に繁殖していたものを空輸し，一たん比較的小さな人 工の池に繁殖させた後, 二次, 三次の放魚を行なって, 1971 年 8 月から 広範な増殖を 認めるようになり, 下水 溝, 湿原地帯などの蚊幼螞除に顕著な効果をみるにい たったものである.

\section{II. 野外調查成緬}

\section{1. 蚊に関する調査}

\section{1 調查経過}

徳島市およびその周辺において，カダヤシの放魚に先 立ち蚊に関する全般的な調查をすすめた。これには，幼 虫発生源を探して各種類ごとの分布地図を作製するこ と，ライトトラップを定点に設置し，每週 1 回の成虫採 集を行なうことを主な作業とした。なお材料の一部は佐 藤が東京にもちかえり，毎年执よそ 11 月より 3 月末ま での 4 か月余りは医科研の研究室内でその分類と，力ダ ヤシその他胎生メダカ類に関する基礎実験を行なった. 1.2 蚊の種類と主要発生源

徳島市およびその周辺でこの期間に採集された蚊の種
類と，その主要発生源は次のとおりである.

Anopheles sinensis Wiedemann, 1828 シナハマダラ 力，水田，沼

Culex bitaeniorhynchus Giles, 1901 カラッイエカ, 水田

Culex tritaeniorhynchus Giles, 1901 コガタアカイエ 力, 水田, 沼

Culex pseudovishnui Colless, 1957 シロハシイエカ, 水田

Culex orientalis Edwards, 1921 八マダラウスカ, 水 田

Culex pipiens pallens Coquillette, 1898 アカイエカ, 下水溝，沼

Culex pipiens molestus Forskal, 1775 チカイエカ, ビルの地下水槽

Culex rubithoracis (Leicester, 1908) アカッノフサ 力, 沼

Culex infantulus Edwards, 1922 フトシマフサカ, 天水溜

Culex vorax (Edwards, 1921) トラフカクイカ，下 水漊

Aedes albopictus (Skuse, 1859) ヒトスジシマカ，墓 石, 竹筒

Aedes togoi (Theobald，1907）トウゴウヤブカ，水誦 Aedes japonicus (Theobald, 1901) ヤマトヤブカ, 墓 石

Aedes dorsalis (Meigen, 1830) セスジヤブカ，海岸 近くの半海水の沼

Aedes vexans nipponii (Theobald, 1907) キンイロヤ ブカ，水田

Armigeres subalbatus (Coquillett, 1898) オオクロヤ ブカ, 肥料溜

以上の各種のうち，とくに大量の発生が注目されたの 法アカイエカで，市内各所の排水ができない下水溝にお びただしく見出された活か，下水が流入する湿地帯， 水田の一部などにも多数の幼虫が見出された。市周辺 の水田，湿地などにシナ八マダラカ，コガタアカイエ カ，カラッイエカなどが発生していたことは当然であ る。また，この地域に特殊な問題として，海岸近くに塩 分濃度が 1 〜 $1.5 \%$ に達するアシの生えた湿原があり， それにシナ八マダラカのほか，七スジヤブカが繁殖して いることが注目された，本種は大雨のあと湿原が冠水 すると卵がかえって，その拉よそ 10 日後から成虫が大 発生することが特徴で，我々の観察期間においても 1969 年 8 月 22 日上り 23 日にかけて台風 9 号により同市にお よそ $80 \mathrm{~mm}$ の豪雨があったあと，9月1日から市内北 
沖洲町の約 30 ヘクタールにわたる湿原にセスジヤブカ 成虫が大発生して近くの約 670 戸の住民に被害が出た. なお，この大雨の前は 8 月 1 日から 22 日までは全く降 雨がなく，湿原はかなり乾燥していた。 さらに 1970 年 4 月 24 日， 25 日に約 $60 \mathrm{~mm}$ の豪雨があったあと， 5 月 1 日から 10 日にかけて同じ地域でセスジヤブカの大 発生があった：このさいは，それ以前にも 4 月 11 日に $46 \mathrm{~mm}, 18$ 日に $24 \mathrm{~mm}$ の雨があって，そのころから一 部幼虫の発生があったものと考えられる。セスジヤブカ の吸血による被害は個人差が大きいが，感受性の強い人 に损いては医師が水痘 varicella ではないかと考えたほ どの水疮性の反応をおこす例も多くみられた。なお，後 述するように，沖洲方面の湿原には 1969 年 10 月に力ダ ヤシを約 100 尾放したあと，1970年 8 月よりその大繁殖 がみられ，それ以後は蚊幼虫の発生がなくなり，七スジ ヤブカの被害も皆無となった。

1.3 ライトトラップによる蚊成虫の捕集成績
徳島市およびその周辺地域での蚊の各種の分布と発生 密度を調べる目的で 1969 年 5 月から 1971 年秋までライ トトラップ（富士平スーパーライトトラップ，ブラック ライト FHK $6 \mathrm{~W}$ ) を第 1 図の地点に設置し，冬期を除 く蚊の発生期間を通じておおむね毎週 1 回の割で各地点 の蚊の採集を行なった，設置地点は次の 7 力所で，1969 年度は(1)(2)(3)(4)，70 年度は(1)(2)(3)(4)(5)，71 年度は (1)(2) (3)(4)(5)(7)の各地点で観察した（図 1).

(1) 徳島市幸町, 医師会館 4 階屋上, 市街地

(2) 徳島市八万町，佐野邸，水田地带

(3) 徳島市新浜本町, 第一病院軒先, 湿原地帯

(4) 徳島市川内町, 水田地带

(5) 徳島市幟町, 大久保邸, 市街地

(6)阿南市の豚舎内, 水田地帯 (図外)

(7) 美馬町の豚舎内, 水田地帯（＂）

全期間を通じて採集された蚊成虫は，シナハマダラ カ, アカイエカ, コガタアカイエカ, シロハシイエカ,

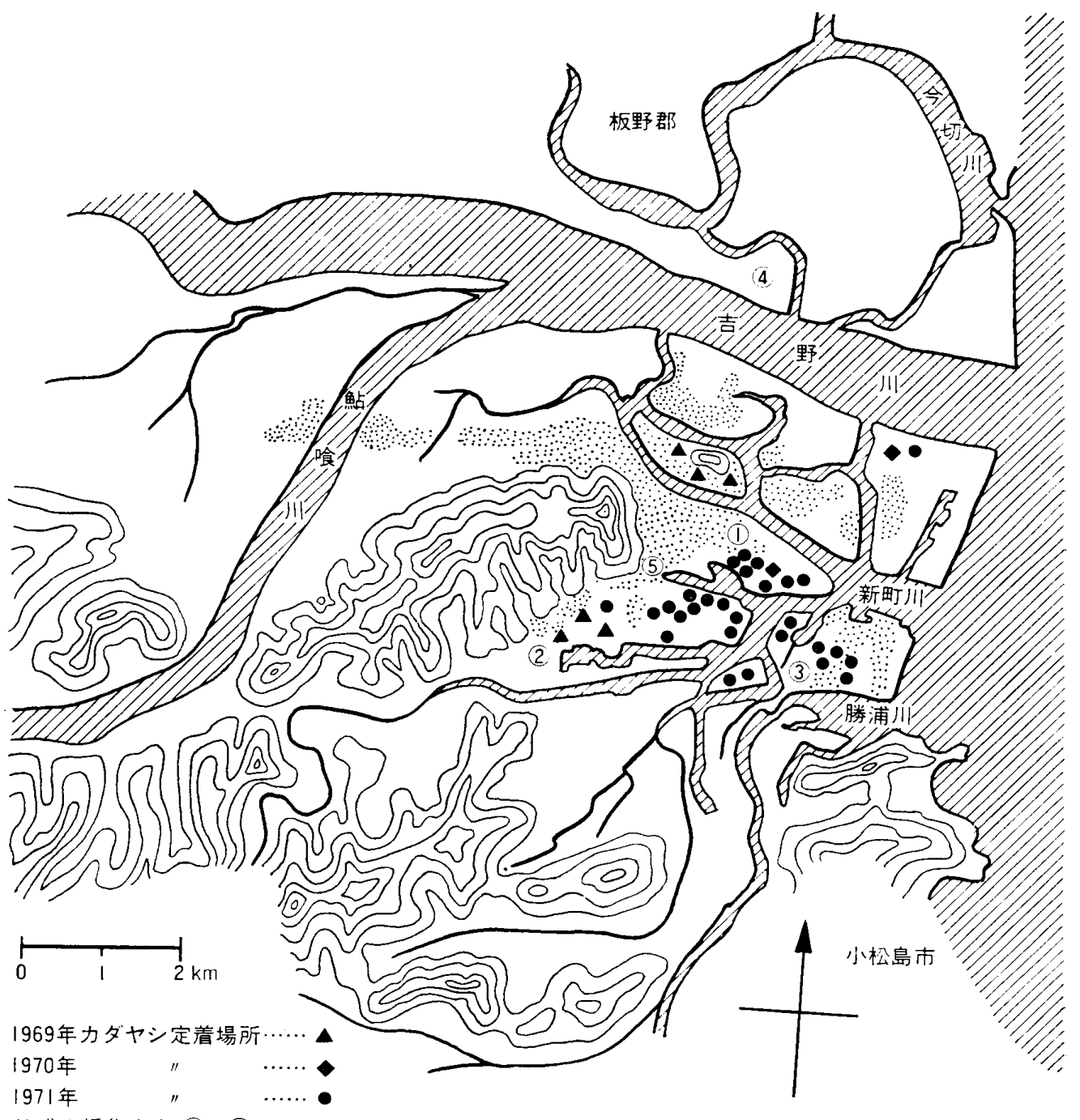

蚊成虫採集定点 (1) - (5)

(6),7)は本交参照)

図 1 徳島市に打けるカダヤシの定着地点扎よびライトトラップ設置地点 
表 1 徳島市および周辺でライトトラップで採集された蚊の年間総数

採集地点 1 . 徳島市幸町, 医師会館 4 階屋上; 2. 徳島市八万町, 佐野氏宅, 水田地带;

3. 徳島市新浜本町, 第一病院軒先, 湿原地帯; 4. 徳島市川内町, 水田地帯;

5. 徳島市幟町, 大久保邸, 市街地；6. 阿南市豚舎； 7. 美馬町豚舍

\begin{tabular}{|c|c|c|c|c|c|c|c|c|c|c|}
\hline \multirow{2}{*}{$\begin{array}{l}\text { 採集 } \\
\text { 地点 }\end{array}$} & \multirow{2}{*}{ 年 度 } & \multirow{2}{*}{ 期 } & \multicolumn{2}{|c|}{ An. $\sin$} & \multicolumn{2}{|c|}{ C. p.p. } & \multicolumn{2}{|c|}{ C. trit } & \multirow{2}{*}{ 他 } & \multirow{2}{*}{ 不 } \\
\hline & & & 우 & $\hat{\sigma}$ & 우 & 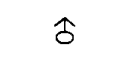 & 우 & 今 & & \\
\hline \multirow{3}{*}{1} & 1969 & $5.22 \sim 10.29$ & 33 & 5 & 183 & 114 & 159 & 16 & 0 & 16 \\
\hline & 1970 & $3.16 \sim 10.21$ & 3 & 1 & 75 & 16 & 44 & 7 & 0 & 0 \\
\hline & 1971 & $5.12 \sim 11.24$ & 31 & 6 & 297 & 90 & 68 & 25 & 0 & 0 \\
\hline \multirow{3}{*}{2} & 69 & $6.11 \sim 10.29$ & 200 & 197 & 1,502 & 1,259 & 395 & 301 & 17 & 77 \\
\hline & 70 & $4.21 \sim 10.28$ & 82 & 32 & 1,230 & 413 & 201 & 83 & 7 & 0 \\
\hline & 71 & $5.12 \sim 10.21$ & 43 & 10 & 1,081 & 495 & 75 & 65 & 22 & 0 \\
\hline \multirow{3}{*}{3} & 69 & $5.22 \sim 10.29$ & 189 & 108 & 4,122 & 10,871 & 3,315 & 6,575 & 45 & 446 \\
\hline & 70 & $4.09 \sim 10.28$ & 105 & 130 & 3,255 & 5,807 & 1,609 & 1,397 & 16 & 0 \\
\hline & 71 & $5.12 \sim 11.24$ & 156 & 98 & 3,235 & 7,278 & 1,844 & 1,491 & 15 & 0 \\
\hline 4 & 69 & $5.22 \sim 10.29$ & 272 & 147 & 363 & 361 & 162 & 32 & 88 & 96 \\
\hline \multirow{2}{*}{5} & 70 & $4.24 \sim 10.28$ & 23 & 22 & 675 & 662 & 224 & 334 & 21 & 0 \\
\hline & 71 & $5.12 \sim 11.24$ & 8 & 3 & 482 & 424 & 15 & 39 & 20 & 0 \\
\hline 6 & 71 & $6.28 \sim 8.23$ & 5,686 & 594 & 5,782 & 279 & 12,966 & 148 & 399 & 261 \\
\hline 7 & 71 & $6.28 \sim 8.23$ & 51,804 & 2,820 & 40,861 & 2,651 & 149,705 & 1,739 & 314 & 23,812 \\
\hline
\end{tabular}

カラッイエカ, アカクシヒゲカ,トラフカクイカ, ヒト スジシマカ, セスジヤブカ, キンイロヤブカ, オオクロ ヤブカの 11 種で, このらちはじめの 3 種 が大部分を占 めていた. アカクシヒゲカは湿原に近い(3)(4)地点のみで 採集された。

また，市外の農村地帯の豚舎を代表する(6)，(7)地点を 除いては, 市内とその周辺ではすべてアカイエカが最多 数を占め, コガタアカイエカ, シナハマダラカの順であ った. 各地点の毎週の採集数を各年度ごとに総計した成 績を表 1 に示す.

これをみると，市街地の(1)，(4)，(5)地点は総数が少な く, アカイエカが優占しているがコガタアカイエカ, シ ナハマダラカも相当数が捕えられていることが注目され る. 湿原に囲まれた(2), (3)地点では採集蚊数は市街地よ りはるかに多く，しかもアカイエカが優占していること が注目される。

各地点の各年ごとの総数を比較すると，おおむね 1969 年が最も多くて，1970 年が少なく，1971年はむしろ前 年より若干多い傾向がみられる。 カダヤシは 1969 年に 移入し，1970 年， 71 年に広く放魚し，その繁殖が各地 でいちぢるしくなったのは 1971 年の夏以後であるから， 沖洲町の湿原を例にとってもその蚊幼虫駆除効果は同年 の後半から現われて㧍り，1972 年以降の 観察成績がど うなるかに興味がもたれる。なお，1970年に観察をは

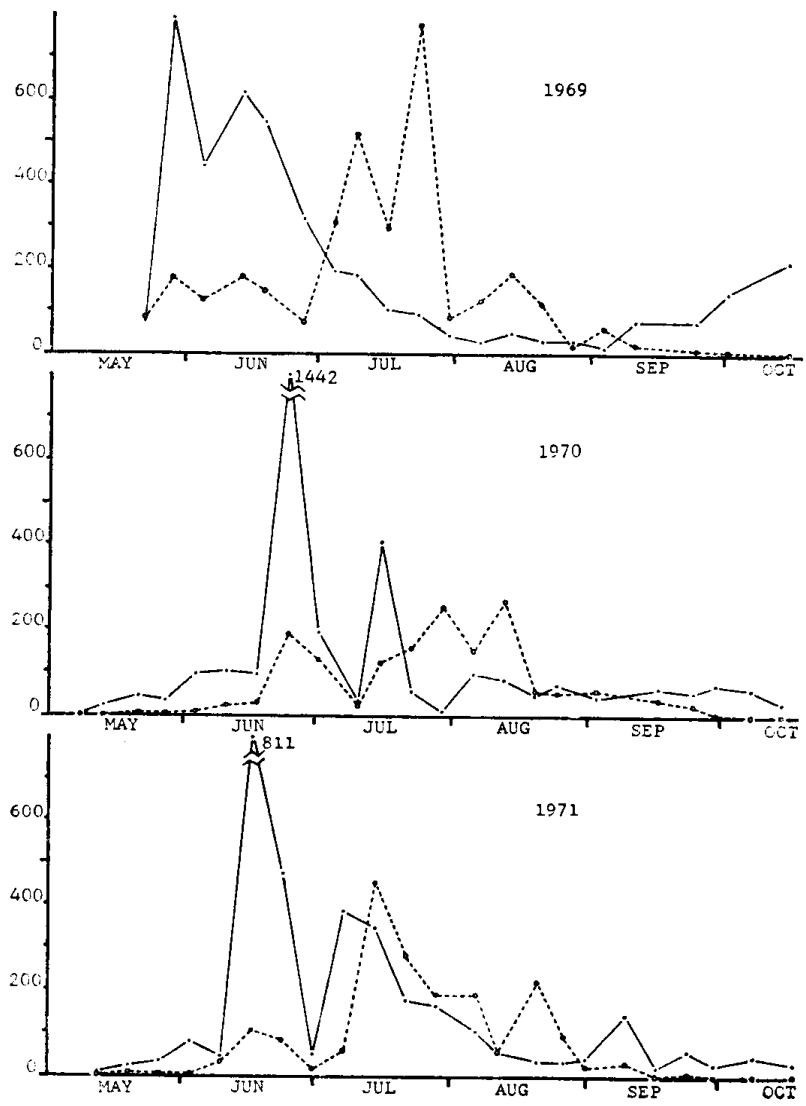

図 2 徳島市第 3 定点でライトトラップに毎週採集 きれたアカイェカ早とコガタアカイエカㅇの数
-.. C. pip. pal.
C. tri. sum. 
じめた市街地の5地点では，71年にはアカイエカ，コガ タアカイエカ, シナハマダラカのいずれもが前年より減 少していることが注目される。

各種ごとの季節消長については，詳細なデータは省略 するが，各地点とも扮括むねアカイエカは 6 月中旬，下 旬に発生のピークを示して 8 月は減少し，9月に再び小 さなピークを示す傾向がみられるのに反して，コガタア カイエカは 7 月中旬, 下旬にピークを生じている。湿原 に囲まれた(3)地点について，各年度の両種の採集数を図 示したのが図 2 である。

\section{2. カダヤシの移殖成縝}

\section{1 カダヤシの輸送と放魚}

我々は 1968 年から 69 年にかけ徳島市周辺の水域を蚊 幼虫調査にともなってひろく観察したが，その限りにお いてはこの地域にカダヤシがあらかじめ繁殖していた形 跡は全くなかった。徳島市への移入は，まず大久保が 1968 年 11 月に東京を訪ねたさい，医科研に飼育中の東 京羽田空港産のカダヤシを約 200 尾携行してその一部を 大久保邸内の庭石とコンクリートで作られた面積約 7 $\mathrm{m}^{2}$, 深さ約 $30 \mathrm{~cm}$ の池に放した.

その後の輸送と放魚経過㳄次のとおりで，いずれも羽 田空港内の溝で採集したカダヤシ成魚を清水に移した 後, $25 \mathrm{~cm} \times 30 \mathrm{~cm}$ のポリエチレン袋に約 $1.5 l$ の清水 を入れ，その 2 袋に約 200 尾ずつ移し，酸素をボンベか ら袋内に充继し，口を輪ゴムで閉じ，ダンボール箱に包 装した上，翌日の航空貨物便のキャビン保管扱いで徳島 空港に輸送した。徳島市では空港でこれを受取った後, 同じ日の内に次の各所に放した。

第 1 回輸送，1969 年 4 月 17 日，合計約 400尾，うち 130 尾を徳島公園内の面積䄪 $100 \mathrm{~m}^{2}$, 深さ $40 \mathrm{~cm}$ の池 に, 50 尾を大久保邸内の上述の池内に, 徳島市八万町の 下水暳 2 か所に 30 尾ずつ放した。

第 2 回輸送，5月 7 日，合計約 400 尾，5ち220尾索 徳島公園内の面積約 $500 \mathrm{~m}^{2}$, 墚さ約 $60 \mathrm{~cm}$ の堀に，八 万町の廃田と下水溝に 50 尾ずつ，残余は防蚊研究室等 の水槽に保存した。

\section{2 繁殖状況と二次放魚以後の成績}

以上の堀・池 3 か所, 下水溝と廃田 3 か所に放した力 ダヤシはいずれもその場所で生育と繁殖が認められ，約 2 か月後の 1969 年 5 月末には若干の稚魚が確認され, 7 月末にはそれらが成魚に発育した。 7 月末に 100 尾を 徳島市北方約 $13 \mathrm{~km}$ にある松茂町の 徳島空港付近の湿 地帯に放した。 さらに 10 月には 3 代目の魚が各地点で おびただしく繁殖しはじめたので，市内 63 か所の下水 溝, 湿地帯などに 1 か所 50 ないし 100 尾の 割合で放す 作業を行なったが，これら二次放魚地点では間もなく冬
となったため，翌年春までに増殖した形跡は認められな かった。

1970 年は 4 月からそれら前年に放魚した地点の 観察 をはじめたが，最初に放魚した 3 か所の池，堀のほかに はカダヤシの姿は見られなかった。しかし8月には，前 年 10 月に二次放魚した昭和町の下水溝と, 北沖洲町の 海岸に接する面積約 30 ヘクタールに達する 広大な湿地 带で，ほほ全面にわたりカダヤシの棲息が認められ，10 月には径 $30 \mathrm{~cm}$ の網で一すくい50〜100 尾ていど捕獲 しうる高い密度に達した。

同年 10 月からこの湿地帯で採集したカダヤシを德島 市内の 73 か所の水たまりに三次放魚した。 な㧍，この 湿地帯では 1969 年にはコガタアカイエカ, アカイエカ, セスジヤブカ，シナハマダラカ幼虫のおびただしい発生 が認められ，付近住民の被害，とくにセスジヤブカによ る皮膚炎の多発がいちじるしかったが，1970 年夏以後は 蚊幼虫が全く採集されなくなったのは，カダヤシの繁殖 にもとづく効果と考えられる。

1971 年には 4 月から再び観察をはじめたが，この年に なってようやくカダヤシの広域にわたる繁殖が認められ るようになり，1969 年，70 年に放魚を試みた場所のう ち36か所でカダヤシがすみつき，繁殖していることが 確認された。そのうち，たこえば山城町のある湿地帯 ではすでに在来種のメダカが多く棲息していた場所に 1969 年 10 月にカダヤシを放したところ，1970年の観 察ではその姿をみなかったが，1971 年 8 月になって急 にカダヤシのいちじるしい繁殖が見出され，このときに はメダカとカダヤシはほぼ同じ密度に達していた。

1971 年度には，すでに沖洲の湿地なじで春から大量の カダヤシを捕えるこしができるようになったため，従来 のよらに 100 尾程度を種付けの目的で放魚する段階か ら，蚊幼虫の発生している下水溝などに 1 回に数千尾之 いう単位でその直接駆除を試みる方法も実施した。

以上の成績をまと的ると，1968 年秋以後，東京から 3 回にわたり移入した合計 1,000 尾足らずのカダヤシを 2 年半ほどの期間に二次三次の放魚段階をへて図 1 に示寸 ように徳島市内と周辺の池，堀，下水溝，休耕田，沼 地，水田などにおびただしく繁殖させることができた。

\section{3 他地域一の輸出}

われわれの調查によっても，力ダヤシは現在の日本に㧍 いて, 福島県内郷, 東京の周辺, 高知市などにもその存 在がたしかめられ，他にもその棲息が報ぜられていると ころもいくつかあるが，今日においてはすでに徳島市ほ ど大量で高密度の繁殖がみられ，容易にまとまった数が 捕獲できる地域は他にないと思われる。したがって，す でにいくつかの地方公共団体などからその分与を求めら 
表 2 徳島市のカダヤシ輸出記録（1971年末まで）

\begin{tabular}{|c|c|c|c|c|c|}
\hline 輸 出 年 月 日 & 請 求 者 & 輸 & 出 & 先 & 輸 出 概 数 \\
\hline 1970年 8月 4 日 & \multirow{2}{*}{$\begin{array}{l}\text { 鹿児島県衛生部 } \\
\text { 大阪大学微生物病研究所 }\end{array}$} & \multirow{2}{*}{\multicolumn{3}{|c|}{$\begin{array}{c}\text { 指 宿 市 } \\
\text { 香川県観音寺 }\end{array}$}} & 1,000 \\
\hline 8月 6 日 & & & & & 1,000 \\
\hline 1971年 4月 5日 & 小 松 島 市（徳島県） & 同 & & 左 & 1,500 \\
\hline$\prime \prime$ & 町 ( $\prime \prime)$ & 同 & & 左 & 500 \\
\hline 4月 9 日 & 小松 島市（" & 同 & & 左 & 2,500 \\
\hline$\prime \prime$ & 北島 町（＂， & 同 & & 左 & 3,000 \\
\hline 4月 10 日 & 牟岐町漁業組合（"） & 同 & & 左 & 1,500 \\
\hline 4月 14 日 & 阿南市( $" \prime)$ & 同 & & 左 & 2,000 \\
\hline 4月 17 日 & \multirow{2}{*}{$\begin{array}{l}\text { 岡山大学寄生虫学教室 } \\
\text { 福岡県衛生部 }\end{array}$} & 岡 & 山 & 市 & 1,000 \\
\hline 4月 19 日 & & 福 & 岡 & 市 & 1,000 \\
\hline 4月 24 日 & \multirow{4}{*}{\begin{tabular}{lll} 
剛 & 山 & 県 \\
高 & 砂 & 市 (兵庫県) \\
松 & 江 & 市（島根県） \\
\multicolumn{1}{l}{ 岡山大学㟢生虫学教室 }
\end{tabular}} & 岡 & 山 & 市 & 2,000 \\
\hline 5 月 13 日 & & 同 & & 左 & 1,500 \\
\hline 5 月 15 日 & & 同 & & 左 & 1,000 \\
\hline 5 月 18 日 & & 岡 & 山 & 市 & 5,000 \\
\hline 5月 27 日 & 津 田 町 (香川県) & 同 & & 左 & 1,000 \\
\hline 6 月 2 日 & 岡出市 & 同 & & 左 & 2,000 \\
\hline 6 月 5 日 & 商 知 市 & 同 & & 左 & 100 \\
\hline 7月 2 日 & 白泉町（香川県） & 同 & & 左 & 1,000 \\
\hline 7月18日 & 兵庫県社会保険所 & 神 & 戸 & 市 & 1,000 \\
\hline 7月 19 日 & 藤 井 寺 市（大阪隹） & 同 & & 左 & 200 \\
\hline 7月 22 日 & 板野町（徳島県） & 同 & & 左 & 100 \\
\hline$\prime \prime$ & 大和 郡 山市 (奈良県) & 同 & & 左 & 1,000 \\
\hline 7月 23 日 & 高松＼cjkstart市（香川県） & 同 & & 左 & 700 \\
\hline 7月28日 & 小 野 市（兵庫県） & 同 & & 左 & 1,000 \\
\hline 8月 4 日 & 松 山 市（愛媛県） & 同 & & 左 & 1,500 \\
\hline 8月14日 & 大 野 原 町（香川県） & 同 & & 左 & 500 \\
\hline 8月18日 & 防售 市（山口県） & 同 & & 左 & 1,500 \\
\hline 8 月 20 日 & 吉 井 保 健 所（長崎県） & 同 & & 左 & 2,500 \\
\hline 8月 24 日 & 富山県衛生研究所 & 富 & 山 & 市 & 1,000 \\
\hline 9 月 29 日 & 香川県農業試験場 & 高 & 松 & 市 & 300 \\
\hline 10月 15 日 & 熊 野 町（広島 県） & 同 & & 左 & 150 \\
\hline 10 月 25 日 & 琉球政府家畜衛生試験場 & 那 & 覇 & 市 & 300 \\
\hline 11月 4 日 & 広島県海田保健所 & 海 & 田 & 市 & 300 \\
\hline
\end{tabular}

れてきた. その主要な例をあげておくことは今後のカダ ヤシの日本における動向を知るうえにも必要と考え, こ れを表 2 に示した。

\section{3. カダヤシ放魚の蚊幼虫駆除効果}

\section{1 カダヤシ定着水域での観察}

上述の作業によりカダヤシが新たにすみついた水系（下 水溝, 湿地など) について蚊幼虫 (主としてアカイエカ) の駆除効果を観察した成績を表 3 に示す.

観察個所は1969年度は 6，らち3 ははじめには蚊幼虫 の発生がみられたが,放魚後に蚊幼虫は消失した。また， 他の 3 か所ははじめから蚊幼虫の発生がみられなかった 池である. 1970 年度には 7 か所のうち 4 か所では放魚
後に蚊幼虫が駆除され，3 か所はもともと蚊幼虫はいな かった. 1971 年度には 36 か所（池 3 ，下水溝 16 , 休业 田 4, 沼13）にカダヤシの放魚後繁殖を認めたらち, 池 3 はもともと蚊幼虫がいなかったが，下水溝の16 中， 12 と休耕田および沼のす心゙ては，放魚前は蚊幼虫がいた ものがその後消失した．ただし下水溝の 4 か所 (25\%) ではカダヤシがすみついたにもかかわらず，蚊幼虫はい ぜんとして存在していたが，これはごみなどのためカダ ヤシの到達しえない場所があるためと考えられた。

なお，カダヤシを放った水城にはもともとメダカがす みついていたところも多く，表 3 に示すよ5にそれは 1969 年度分で 6 か所中 5,1970 年で 7 か所中 6,1971 
表 3 カダヤシのすみついた水域における蚊幼虫とメダカの棲息状況

\begin{tabular}{|c|c|c|c|c|c|c|c|c|c|c|c|}
\hline \multirow{2}{*}{$\begin{array}{l}\text { 年度 } \\
\text { 氷域数 }\end{array}$} & \multirow{2}{*}{\multicolumn{3}{|c|}{ 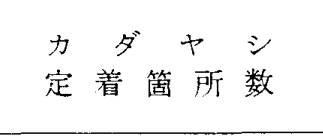 }} & \multicolumn{4}{|c|}{ 蚊幼虫発生への影響 } & \multicolumn{3}{|c|}{ メダカの棲息 } & \multirow{2}{*}{$\begin{array}{c}\text { かつ下 } \\
\text { ×ダカと } \\
\text { 蚊幼虫あり }\end{array}$} \\
\hline & & & & 消失した & 消失せず & 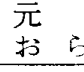 & b 来 & あ & b) & な & \\
\hline \multirow{3}{*}{$\begin{array}{c}1969 \\
6\end{array}$} & 池, & 堀 & 3 & 0 & 0 & & 3 & & 2 & 1 & 0 \\
\hline & 下 水 & & 2 & 2 & 0 & & 0 & & 2 & 0 & 2 \\
\hline & 休 耕 & 田 & 1 & 1 & 0 & & 0 & & 1 & 0 & 1 \\
\hline \multirow[t]{2}{*}{1970} & 池， & 堀 & 3 & 0 & 0 & & 3 & & 2 & 1 & 0 \\
\hline & 下 水 & 溝 & 2 & 2 & 0 & & 0 & & 2 & 0 & 2 \\
\hline \multirow[t]{2}{*}{7} & 休 耕 & 田 & 1 & 1 & 0 & & 0 & & 1 & 0 & 1 \\
\hline & 沼 & & 1 & 1 & 0 & & 0 & & 1 & 0 & 1 \\
\hline \multirow[t]{2}{*}{1971} & 池, & 堀 & 3 & 0 & 0 & & 3 & & 2 & 1 & 0 \\
\hline & 下 水 & 溝 & 16 & 12 & 4 & & 0 & & 3 & 13 & 3 \\
\hline \multirow[t]{2}{*}{36} & 休 耕 & 田 & 4 & 4 & 0 & & 0 & & 2 & 2 & 2 \\
\hline & 沼 & & 13 & 9 & 0 & & 4 & 1 & 3 & 0 & 9 \\
\hline
\end{tabular}

年で 36 か所中 20 か所におよんでいる. しかし，メダカ

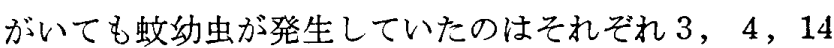
か所におよんでいる。それれカダヤシを放したあとはじ めて蚊幼虫が消失した例が多い：これをみても蚊幼蟖 除效果はカダヤシの方がすぐれていることが分かる.

3.2 下水满に大量放魚後の蚊幼虫駆除効果

カダヤシを下水溝に放魚した後に，アカイエカ幼虫の
棲息密度がどう変化するかを 観察した成績を表 4 に示 す．I，II，III群の下水溝について，それぞれ定距離お きに観察点 $\mathrm{A}, \mathrm{B}, \mathrm{C}$, 等を作り, その地点においてカ ダヤシが見出された場合には太字にして，各地点の蚊幼 虫数はヒシャク 5 杯の合計が $1 \sim 10$ 匹の場合を $1,11 \sim$ 100 匹の場合を $2 ， 101 \sim 1,000$ 匹の場合を 3 ，それより 多い場合を 4 とした。

表 4 下水溝にカダヤシ放魚後のアカイエカ幼虫発生密度の消長

数字汢すくい取り法による棲息密度, ヒシャク 5 回につき 1:(1〜10匹), 2：

$(11 \sim 100$ 匹) , $3:(101 \sim 1000 匹), 4:$ (1001 匹以上)；太字 : カダヤシ十

\begin{tabular}{c|l|lll|c}
\hline \hline 第 I 群 & 水 温 & A & B & C & 対照 \\
\hline 7月 24 日 & $28^{\circ} \mathrm{C}$ & 3 & 3 & 3 & 3 \\
25 & 28.5 & 3 & 3 & 4 & 3 \\
27 & 31 & $\mathbf{2}$ & $\mathbf{2}$ & 3 & 4 \\
28 & 30.5 & $\mathbf{2}$ & $\mathbf{3}$ & 3 & 4 \\
30 & 31 & $\mathbf{1}$ & $\mathbf{1}$ & 3 & 4 \\
8 月 2 & 33 & $\mathbf{1}$ & $\mathbf{1}$ & 3 & 4 \\
4 & 32 & $\mathbf{0}$ & $\mathbf{1}$ & 4 & 3 \\
6 & 30.5 & $\mathbf{1}$ & $\mathbf{2}$ & 4 & 4 \\
8 & 31 & $\mathbf{2}$ & 3 & 3 & 4 \\
10 & 31 & $\mathbf{1}$ & $\mathbf{2}$ & 4 & 4 \\
12 & 28 & $\mathbf{1}$ & 3 & 4 & 4 \\
15 & 27 & $\mathbf{0}$ & 3 & 4 & 4 \\
19 & 30 & $\mathbf{0}$ & 3 & 3 & 4 \\
23 & 27 & $\mathbf{0}$ & $\mathbf{2}$ & 3 & 4 \\
25 & 30 & $\mathbf{0}$ & $\mathbf{1}$ & 4 & 4 \\
27 & 28 & $\mathbf{0}$ & $\mathbf{1}$ & 4 & 4 \\
30 & 30 & $\mathbf{0}$ & $\mathbf{0}$ & 4 & 4 \\
\hline
\end{tabular}

\begin{tabular}{|c|c|c|c|c|c|c|c|c|c|c|c|c|c|}
\hline 第 II 群 & 水温 & $A$ & & B & C & D & & $\mathrm{E}$ & $\mathrm{F}$ & G & & $\mathrm{H}$ & 対照 \\
\hline 8 月 13 日 & $30^{\circ} \mathrm{C}$ & 4 & & 4 & 4 & 4 & & 4 & 3 & 4 & & 4 & 4 \\
\hline 15 & 28 & 4 & & 3 & 2 & 3 & & 0 & 1 & 0 & & 0 & 3 \\
\hline 19 & 30 & 3 & & 1 & 1 & 2 & & 3 & 2 & 0 & & 1 & 4 \\
\hline 23 & 29.5 & 3 & & 3 & 3 & 3 & & 1 & 3 & 2 & & 0 & 3 \\
\hline 25 & 30.5 & 4 & 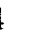 & 3 & 4 & 4 & & 3 & 0 & 0 & & 0 & 3 \\
\hline 27 & 29 & 3 & 3 & 3 & 4 & 2 & & 1 & 0 & 0 & & 0 & 3 \\
\hline 30 & 30 & 2 & 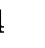 & 2 & 3 & 4 & 4 & 0 & 0 & 0 & & 0 & 4 \\
\hline 9月 1 & 29 & 3 & 3 & 3 & 3 & 1 & 1 & 0 & 0 & 0 & & 0 & 4 \\
\hline 第 III群 & 水温 & A & B & $\mathrm{C}$ & $\mathrm{D}$ & $\mathrm{E}$ & $\mathrm{F}$ & $\mathrm{G}$ & $\mathrm{H}$ & I & $\mathrm{J}$ & $\mathrm{K}$ & 対旦 \\
\hline 8 月 13 日 & $28^{\circ} \mathrm{C}$ & & & 4 & 4 & 4 & 4 & 4 & 2 & 4 & 4 & 4 & 4 \\
\hline 15 & 27 & 4 & 4 & 3 & 3 & 3 & 3 & 3 & 3 & 1 & 0 & 0 & 4 \\
\hline 16 & 30 & 0 & 4 & 4 & 3 & 3 & 3 & 4 & 3 & 3 & 0 & 0 & 4 \\
\hline 19 & 29 & 0 & 2 & 1 & 0 & 0 & 1 & 1 & 3 & 0 & 0 & 0 & 4 \\
\hline 25 & 30 & 0 & 0 & 1 & 0 & 1 & 2 & 1 & 1 & 1 & 0 & 0 & 4 \\
\hline 27 & 29 & 0 & 0 & 3 & 4 & 2 & 1 & 3 & 3 & 2 & 0 & 0 & 4 \\
\hline 30 & 28 & 0 & 0 & 3 & 3 & 2 & 1 & 3 & 1 & 0 & 0 & o & 3 \\
\hline 9 月 1 & & 0 & 1 & 0 & 0 & 1 & 3 & 4 & 2 & 0 & 0 & 0 & 4 \\
\hline
\end{tabular}


120

第 I 群の下水溝は長さ各 $15 \mathrm{~m}$, 深さ $20 \mathrm{~cm}$, 幅 $2 \mathrm{~m}$ で，1970年 7 月 24 日に A，B，C と対照区に幼虫がそ れぞれ密度 3 の発生を示していることを確認した上，力 ダヤシを Aに 400 尾， B，Cに 300 尾放した．その結 果, カダヤシのいない対照区には 8 月 30 日まで密度 3 〜 4の発生がみられたが，A区では7月 27 日よりカダ ヤシの存在がみられ，その定着と繁殖にともない 7 月末 より密度 1 ないし0に減少している，Bではカダヤシの 増殖がおそく，8 月初旬にはその存在が認められずに蚊 幼虫も密度 $2 \sim 3$ に発生したこともあるが，8月 30 日 にいたり蚊幼虫は消失した，C区では家庭下水の排水溝 の直下で，カダヤシはすみつけず，蚊幼虫は $3 \sim 4$ と発 生をつゔけた（表 4-I）.

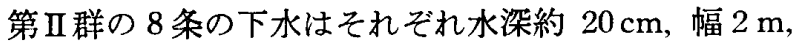
長さ $8 \mathrm{~m}$ で, 1970 年 8 月 13 日にカダヤシを 150 尾ず つ, 計 1,200 尾放し，9月1日まで 8 回の観察をおこな ったが，カダヤシがすみついて繁殖した $\mathrm{E} \sim \mathrm{H}$ の漂では いずれも蚊幼虫は消失し，それがすみつきえなかった $\mathrm{A}$ 〜 C , 対象区ではこの期間中密度 $3 \sim 4$ の蚊幼虫発生

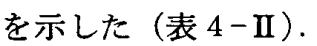

第III群の下水溝はそれぞれ水深約 $20 \mathrm{~cm}$, 幅 $2.5 \mathrm{~m}$, 長さ $5 \mathrm{~m}$ のもの 12 条で，カダヤシを 1970 年 8 月 13 日 に各 100 尾ずつ， $\mathrm{A} \sim \mathrm{K} の 11$ 条に放した. このうち毎 回カダヤシの存在が認められた $\mathrm{A} ， \mathrm{I} ， \mathrm{~J} ， \mathrm{~K}$ では数日 後から蚊幼虫の減少ないし消失がみられ，その他の溝で はカダヤシの芫出されぬ場合には $2 \sim 3$ 度の幼虫発生が 認められたが，カダヤシの存在するさいには 0 ないし

1，2 度と減少効果が明らかであった（表 4-III）。

以上の成績から，下水溝にカダヤシを放した場合，こ のていどの数であってもその定着と繁殖に好適な環境で ある場合には顕著な蚊幼虫駆除効果がみられるが，水質 が不適であったり，水が減少してすみつけなかったりす る場合もあって，そのさいには効果がないか不完全であ った．また，草が密生したり，下水にごみがつまって， カダヤシの到達しえない場所ができると，そこに蚊幼虫 が発生する例もみられた。

\section{4. カダヤシとメダカの関係の野外調査}

徳島市の湿地帯の一部には従前からメダカ Oryzias latipes が繁殖していたが，1969 年 4 月よりカダヤシの 移殖をはじめた後，多くの水域では後者がいちじるしく 繁殖してメダカをすでに駆逐しており，一部ではカダヤ シの繁殖が末だ十分でなく両種が共存している場所もみ られる。ささらに，カダヤシを放した後もいぜんとしてメ ダカが優占している所もある。このように両種は種間競 争の立場にあり，おそらく環境の差と放魚数に応じてそ のバランスがきまるものと考えられる，そこで, 徳島市
衛 生 動 物

における両種の棲息密度，環境条件，食性などの問題に ついて 1971 年 10 月に山岸, 佐藤, 沖野, 和田, 栗原が 次のような野外調査を行なった。

\section{1 調查場所}

カダヤシの放魚後その繁殖がすでに高密度に達した場 所として北沖洲町を，その効果が現われ始めた場所とし て金沢新田，繁殖効果が全くあがらぬ場所として川内町 を選んだ．北沖ノ洲町の調査地は幅約 $3.5 \mathrm{~m}$, 水深 $30 \sim$ $55 \mathrm{~cm}$ の水路で両岸にヨシが密生している．金沢新田の 調查地はネギ畑の間を流れる 幅 $2.2 \mathrm{~m}$ ，水樑 $14 \mathrm{~cm} の$ 流れであり，この場所でのカダヤシの生存は, 本調查に さきだって行なわれた予備調査で初めて確認された. 川 内町の調查地は幅 $2.5 \mathrm{~m}$, 長さ $17 \mathrm{~m}$, 水深 $17 \mathrm{~cm}$ の水 たまりで，少し離れたところにある養魚池の排水が流入 している。 なお, 棲息密度と食性の調査は行なわなかっ たが，カダャシとメダカの混生地として他に山城沼（湿 地）についても若干の資料を得たのであげておく。

\section{2 調查方法}

個体数調查はマーキング法によった。 マーキングは現 場で捕えた魚をニュートラルレッドの $1 / 10,000$ 水溶液 に10２0分間入れて体を赤色に染色して放す．赤色のマ 一ク個体がもとの魚群の中に分散していく様子は肉眼で よく観察できる。この方法はひれ切りなどのマーキング よりも能率的である. 約 1 時間後マーク個体と非マーク 個体の完全な混合が確められたら，魚の捕獲を行なう。 捕獲はたも網を用いると，マーク個体を的らいやすいの で， $1 \times 1 \mathrm{~m}$ の四手網により無差別に行なった。 金沢 新田と川内町では水路の一定区間をサラン網で仕切り， 魚の出入りをとめてこの作業を行なった．個体数の推定 值の計算はリンカン指数法（伊藤，1963）によって行な った。沖ノ洲町は水路を仕切ることができなかったの で，マーキング法をあきらめ，面積 $1 \mathrm{~m}^{2}$ の四つ手網を 15 分間沈めて引上げる（網を沈めたあと人は草むらの かげにかくれ，魚をできるだけ警かさないようにする） ことを場所を変えながら 5 回行ない，その平均值をもっ て密度とした。

植物プランクトンは調查用に水 $250 \mathrm{ml}$ をホルマリン で固定し，動物プランクトンは水 $10 l$ をプランクトン ネットでろ過して採集し，ベントスは一辺 $50 \mathrm{~cm}$ のわ く内の泥を集めてふるいでふるって採集した，捕獲した 魚の一部は直ちにホルマリンで固定し，消化管内容物検 查用に使った。

\section{3 結果と考察}

表 5 に調查場所の水質を示す. いずれも流れはきわめ ておそいかほとんど流れていない場所で，最大の特徴は 塩素イオンがきわめて多いことである。これは吉野川を 
表 5 調查場所の水質（1971年10月23日）

\begin{tabular}{|c|c|c|c|c|c|c|c|c|c|}
\hline & & & $\begin{array}{l}\text { 流速 } \\
\mathrm{cm} / \mathrm{sec}\end{array}$ & ${ }^{\circ} \mathrm{C}^{\text {温 }}$ & ${ }^{\circ}{ }^{\circ} C^{\text {温 }}$ & $\mathrm{pH}$ & $\begin{array}{l}\text { 溶存 酸 素 } \\
\mathrm{O}_{2} \mathrm{mg} / \mathrm{l}(0 \% \text { (o) } \\
\end{array}$ & $\begin{array}{c}\mathrm{Cl}^{\prime} \\
\mathrm{mg} / \mathrm{l}\end{array}$ & $\begin{array}{l}\mathrm{COD} \\
\mathrm{O}_{2} \mathrm{mg} / l\end{array}$ \\
\hline 金 & 沢 新 & 田 & 7.8 & 22.6 & 22.8 & 8.1 & $\begin{array}{l}9.12 \\
(108 \%)\end{array}$ & 14500 & 10.76 \\
\hline 川 & 内 & 町 & 2.8 & $18.3 \sim 19.4$ & $18.8 \sim 19.9$ & 7.3 & $\begin{array}{c}3.80 \sim 5.66 \\
(42.5 \sim 62.0 \%)\end{array}$ & 1410 & 0.94 \\
\hline 沖 & ' & 洲 & l & 22.0 & 22.1 & 8.0 & $\begin{array}{r}7.41 \\
(87 \%)\end{array}$ & 14800 & 13.44 \\
\hline 山 & 城 & 沼 & / & 17.8 & 18.4 & 8.4 & $\begin{array}{l}5.20 \sim 6.20 \\
(57 \sim 68 \%)\end{array}$ & & \\
\hline
\end{tabular}

表 6 マーキング法と四ツ手網法に上る個体数 の推定

\begin{tabular}{|c|c|c|c|c|c|}
\hline 方 法 & \multicolumn{3}{|c|}{ マーキング法 } & \multirow{2}{*}{\multicolumn{2}{|c|}{ 四手網 法 }} \\
\hline 水 域 & \multicolumn{2}{|c|}{ 金 沢 新 画 } & \multirow{2}{*}{$\frac{\text { 川内町 }}{\text { メダカ }}$} & & \\
\hline 魚 種 & カダヤシ & メダカ & & カダヤシ & メダカ \\
\hline $\begin{array}{l}\text { 記号個体 } \\
\text { 数 } \\
R\end{array}$ & 437 & 74 & 647 & 2,083 & 1 \\
\hline 捕獲個体 & 1,990 & 267 & 890 & (5 回計) & (5 回計) \\
\hline $\begin{array}{l}\text { 再捕獲個 } \\
\text { 体数 } r \\
r\end{array}$ & 97 & 7 & 36 & & \\
\hline $\begin{array}{l}\text { 推定総個 } \\
\text { 体数 } \hat{N}\end{array}$ & $\begin{array}{l}8,965 \\
\pm \quad 888\end{array}$ & $\begin{array}{l}2,498 \\
\pm \quad 820\end{array}$ & $\begin{array}{c}16,013 \\
\pm 2,579\end{array}$ & & \\
\hline $\begin{array}{c}\mathrm{m}^{2} \text { 当 } \\
\text { り密度 } \\
\widehat{N} / \mathrm{m}^{2}\end{array}$ & $272 \pm 27$ & $76 \pm 25$ & $377 \pm 61$ & $417 \pm 287$ & 0.2 \\
\hline
\end{tabular}

$\widehat{N}=C R / r, V(\hat{N})=R^{2} C(C-r) / r^{3} ; V$ はバリアンス. $r$ が $R$ の $10 \%$ 以下の上きは次式を用いた。

$\widehat{N}=(C+1) R / r+1 ; V(\widehat{N})=R^{2}(C+1)(C-r) /$

$(r+1)^{2}(r+2)$

通じて海水が入りこむことと関係があり，金沢新田と北 沖ノ洲町の塩分濃度は河口部の汽水域のそれに匹敵す る.しかし両地ともとも COD の值もかなり高いので， 生活排水の影響を受けていると考えられる。

表 6 にマーキング法とすくい取り法によって推定した カダヤシとメダカの個体数と棲息密度を示す。ここで興 味があるのは金沢新田のカダヤシとメダカの合計の棲息 密度が，川内町のメダカおよび北沖ノ洲町のカダヤシと 大差ないことである。このことは $300 〜 500$ 尾 $/ \mathrm{m}^{2}$ 程度 が棲息可能な密度で，カダヤシとメダカは同じ生態的地 位を争っているものと推定される。金沢新田ではカダヤ シを放魚してから 1 年半で，カダヤシがメダカを圧迫す るに至っているが，川内町では 1 年半の期間が経過して もまだ増殖が始まっていない，一方，北沖ノ洲町ではす でにカダヤシが完全にメダカを制圧しているが， 5 回の 採集でただ一尾のメダカが得られたことは，かつてはこ こにもかなりの数のメダカが棲息していたことを想像さ
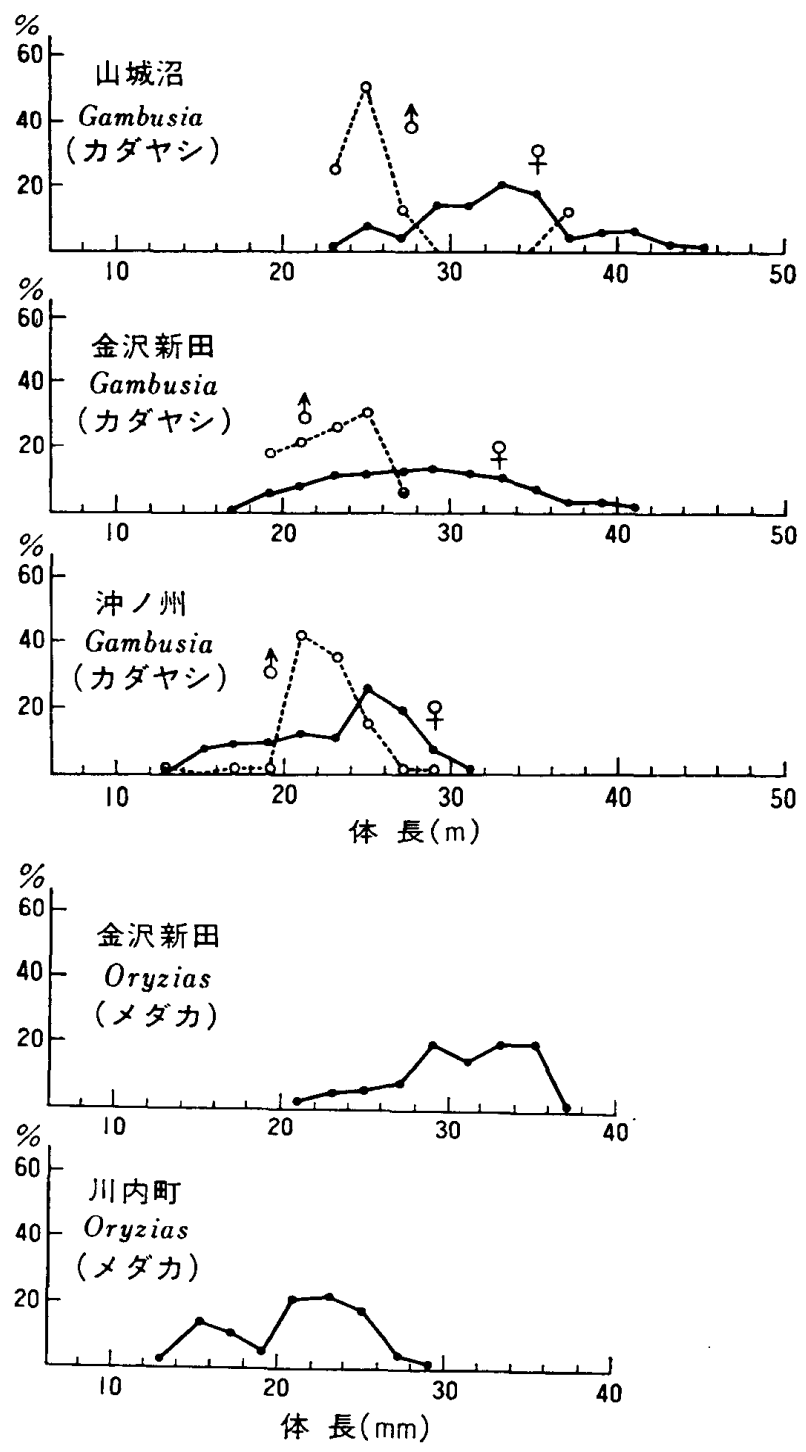

図 3 カダヤシとメダカの体長分布

せるものである。

図 3 に調查地のカダヤシとメダカの体長分布を, 表 7 に体長の平均値とその変動と分布曲線の歪みを示す. 力 ダヤシメダカとも場所によるサイズの差が明睹であ る. 佐藤の観察によると，秋になると大型のカダヤシが 減るとのことであるが，北沖ノ洲町のカダヤシは䧳雄と 
表 7 カダヤシとメダカの体長の平均値と，そ の変動と分布曲線の歪み

\begin{tabular}{|c|c|c|c|c|c|c|c|}
\hline & $\begin{array}{c}\text { 測 } \\
\text { 個体数 } \\
n \\
(\text { 尾) } \\
\end{array}$ & $\begin{array}{c}\text { 平均 } \\
\text { 体長 } \\
\bar{x} \\
(\mathrm{~mm})\end{array}$ & $\begin{array}{c}\text { 標準 } \\
\text { 偏差 } \\
s\end{array}$ & $\begin{array}{l}\text { 変動* } \\
\text { 係数 } \\
C V \\
(\%) \\
(\%)\end{array}$ & $\begin{array}{l}\text { 歪度** } \\
S_{\mathrm{k}}\end{array}$ \\
\hline \multirow{2}{*}{ 沖，洲 } & \multirow{2}{*}{$\begin{array}{l}\text { カダ } \\
ヤ シ\end{array}$} & 今 & 62 & 21.9 & 2.1657 & 9.88 & -0.6503 \\
\hline & & 우 & 75 & 22.8 & 4.2227 & 18.48 & -0.4985 \\
\hline 川内町 & \multicolumn{2}{|c|}{ メダカ } & 101 & 20.9 & 3.8969 & 18.63 & -0.2248 \\
\hline \multirow{3}{*}{ 金沢新田 } & \multirow{2}{*}{$\begin{array}{l}\text { カダ } \\
ヤ シ\end{array}$} & $\hat{0}$ & 109 & 22.4 & 2.4210 & 10.78 & -0.1038 \\
\hline & & 우 & 137 & 27.9 & 5.4975 & 19.70 & +0.2133 \\
\hline & \multicolumn{2}{|c|}{ メダカ } & 163 & 30.6 & 3.8133 & 12.46 & -0.5917 \\
\hline \multirow{2}{*}{ 山城沼 } & \multirow{2}{*}{$\left|\begin{array}{l}\text { カダ } \\
ヤ シ\end{array}\right|$} & $\hat{\sigma}$ & 8 & 26.0 & 4.6828 & 18.01 & +1.5000 \\
\hline & & 우 & 50 & 32.6 & 4.9635 & 15.22 & +0.2747 \\
\hline
\end{tabular}

* $C V=s / \bar{x} \times 100$

** $\quad S_{\mathrm{k}}=\sum(x-\bar{x})^{3} / n s^{3} \quad\left(S_{\mathrm{k}}\right.$ は 正規分布の歪みを示 す指標で $S_{\mathrm{k}}=0$ なら分布曲線が左右対称, $S_{\mathrm{k}}>0$ ならモードが中央值の左に， $S_{\mathrm{k}}<0$ なら 右にかたよる)。

もに，体長のモードが他の 2 地点のそれより明らかに小 さく，これが大型魚の死亡によって起こったとは思われ ない.

表 8 に棲息地の生物相とカダヤシおよびメダカの食性 を示す、カダヤシ，メダカともに植物および動物プラン クトンを主に食べていたが，ベントスは消化管から発見 されなかった。なお，金沢新田と北沖ノ洲町の生物相は 珪藻類の Amphiprora と Pleurosigna, 動物では Polycha eta のように汽水性のものが多い.

以上の調查から，カダヤシはメダカと食物と棲息空間 に関して完全な競争種であるといえる. 放流されたカダ ヤシが 1 年余りの間にその分有城を広げえた理由の $1 つ$ は，メダカが卵生であるのに対してカダヤシが胎生であ って稚魚の生存率が高く，また産子回数が多いことがあ げられる。生まれたばかりの稚魚のサイズはカダヤシが メダカよりはるかに大きいから，メダカの稚魚はカダヤ シの成魚にかなり捕食されると思われる，そのほか，攻 撃性に関しては後述するよらにカダヤシがメダカよりは るかに強烈であるので, 行動による直接の圧迫も軽視で きない要因である。このようにメダカとカダヤシの競争 においては多くの場合カダヤシが有利と考えられるか ら，大量の（少なくとも 1 万尾以上）のカダヤシを 1 水 域に放魚すれば，ごく短い時間でメダカを制圧する可能 性は大きい，毎年放魚してもカダヤシが見られない場所 があるのは 100 尾単位の放魚ではそれがメダカとの競争 において数の上でメダカの圧迫を受けるため急速な増殖
はできないことによるのであろう。このさい注意を要す るのは，カダヤシによるメダカの圧迫が，外来（帰化） 生物による在来の生物相の消隇といら自然破壇の問題に つながることである。

\section{5. カダヤシに関する実験室内钼察}

\section{1 カダヤシの飼育と産子}

カダヤシは近緣のグッピーなどと異なって，普通のガ ラス水槽で飼育してもなかなか子を産まず，また子を産 んでも親が食べてしまって，繁殖させることはできない といらことはわれわれも長年にわたり経験したところ で，防蚊研究室のガラス水槽においても，1970年 4 月に 放したカダヤシは 2 年あまり生存しているが，まったく 増殖はみられない。

しかし, 同じカダヤシも屋外の人工池に放すと, 面積 $4 \mathrm{~m}^{2}$, 深さ $25 \mathrm{~cm}$ ていどの小さな池の場合でもかなり の繁殖がみられた。ささらに大きな池，沼，湿地帯などに おいては，きわめてよく繁殖し，おびただしい捿息密度 に達する，産出から成魚に達するには野外では夏にはお よそ 2 か月を要するにすぎない．これらの問題について の観察成績は別に詳述する予定である。

産子数：カダヤシが 1 回に何尾の子をうむか，また 産子の間隔はどのくらいかについて，野外で十分に発育 した早を繁殖期間の 6 月中旬から 8 月上旬の間に採集 し，個別に水槽にセットした産子箱に放って観察した。 飼料としてはマウス飼育用固型飼料をあたえた，産子数 は表 9 に示すとおりで，この装置内で産子した早の体長 は平均 $3.72 \pm 0.60 \mathrm{~mm}$ (最小 $2.6 \mathrm{~mm}$, 最大 $5.5 \mathrm{~mm}$ ), 1 回の産子数は平均 $67.41 \pm 49.57$ (最少 17 , 最多 213) であった．この成績をみると，山岸ら（1967）がグッピ 一について観察を行なった結果と同じように，産子数と 親の体長の間には高度の相関がみられ，その回帰直線は 素データー（各穴の実测体長 $0.1 \mathrm{~mm}$ 単位, 産子数も 実数）をもとに計算した結果では，y を産子数， $x$ を体 長とすると。

$$
y=70.06 x-193.32
$$

となり，相関係数は $0.852, t=12.28$ という值をえ た。なお，体長と産子数の関係を前者は $0.2 \mathrm{~mm}$ 単位, 後者を 20 尾単位のクラスにまとめて表示したのが表 9 である。その結果，体長はほぼ正規分布を示すが，産子 数については平均值の 67.4 尾より多く産子した 個体は $21.7 \%$ （59 尾中 16 尾）にすぎず，少数の個体が異常な 多産を行なう傾向がみられた.

産子間隔 : カダヤシの早が 1 回子をうんだあと, 何日後 に次の産子を行なうかは自然界で観察することはできな いので，水槽中で飼育したものについてしらべた. 1970 年 6 月〜 7 月の間に野外で採集した早を産子箱に入れ, 
表 8 調查地の生物相とカダヤシ（K）ないしメダカ（M）の消化管に現われたもの

\begin{tabular}{|c|c|c|c|c|}
\hline 生 & 物 & 金沢新田 & 111 内 町 & 北 沖 洲 \\
\hline Cyanophyceae & $\begin{array}{l}\text { Aphanocapsa } \\
\text { Merismopedia } \\
\text { Oscillatoria }\end{array}$ & $++\mathrm{KM}$ & $\begin{array}{l}++ \\
\mathrm{r}\end{array}$ & $+\mathrm{K}$ \\
\hline Diatomeae & $\begin{array}{l}\text { Achnanthes } \\
\text { Amphiprora } \\
\text { Cyclothella } \\
\text { Cymbella } \\
\text { Diatoma } \\
\text { Fragilaria } \\
\text { Melosira } \\
\text { Naricula } \\
\text { Nitzschia } \\
\text { Pleurosigma }\end{array}$ & $\begin{array}{l}++\mathrm{KM} \\
+ \\
\mathrm{r} \mathrm{KM} \\
\mathrm{r} \\
+++ \\
\mathrm{r} \mathrm{KM} \\
+\mathrm{KM} \\
++\mathrm{KM}\end{array}$ & $\mathrm{r} M$ & $\begin{array}{l}\mathrm{r} \\
\mathrm{r} \mathrm{K} \\
\mathrm{r} \\
\mathrm{r} \mathrm{K} \\
\\
++ \\
+ \\
+\mathrm{K} \\
\mathrm{r} \mathrm{K} \\
+\mathrm{K}\end{array}$ \\
\hline Chlorophyceae & $\begin{array}{l}\text { Golenkinia } \\
\text { Pediastrum } \\
\text { Scenedesmus }\end{array}$ & $\mathrm{r}$ & $\begin{array}{l}\mathrm{r} \\
\mathrm{r} \mathrm{M} \\
+\mathrm{M}\end{array}$ & \\
\hline Protozoa & $\begin{array}{l}\text { Ciliata } \\
\text { Euglena } \\
\text { Eudorina } \\
\text { Pandorina } \\
\text { Vorticella }\end{array}$ & + & $\begin{array}{ll}\mathrm{r} & \\
\mathrm{r} & \\
\mathrm{r} & \mathrm{M} \\
\mathrm{r} & \mathrm{M} \\
\mathrm{r} & \end{array}$ & $\mathrm{r}$ \\
\hline Trochelminthes & $\begin{array}{l}\text { Brachionus } \\
\text { Keratella } \\
\text { Polyarthra } \\
\text { Trichocerca }\end{array}$ & & $\begin{array}{ll}\mathrm{r} & \mathrm{M} \\
\mathrm{r} & \mathrm{M} \\
\mathrm{r} & \mathrm{M} \\
\mathrm{r} & \mathrm{M}\end{array}$ & \\
\hline Nemathelminthes & Nematoda & + & & $\mathrm{r}$ \\
\hline Annelida & $\begin{array}{l}\text { Polychaeta } \\
\text { Oligochaeta }\end{array}$ & + & $\mathrm{r}$ & $\begin{array}{l}\mathrm{r} \\
+\end{array}$ \\
\hline $\begin{array}{c}\text { Arthropoda: } \\
\text { Crustacea } \\
\text { Insecta }\end{array}$ & $\begin{array}{l}\text { Ostrachoda } \\
\text { Copepoda } \\
\text { Amphipoda } \\
\text { Chironomidae }\end{array}$ & $\begin{array}{l}+\mathrm{MI} \\
\mathrm{r}\end{array}$ & $\begin{array}{l}\mathrm{r} . \mathrm{M} \\
+\mathrm{M} \\
\mathrm{r}\end{array}$ & $\begin{array}{l}\mathrm{r} \\
\mathrm{r} \\
\mathrm{r}\end{array}$ \\
\hline Vertebrata: & $\begin{array}{l}\text { Carassius carassius } \\
\text { Oryzias latipes } \\
\text { Gambusia affinis }\end{array}$ & $\begin{array}{l}+ \\
+\end{array}$ & $\begin{array}{l}+ \\
++\end{array}$ & $\begin{array}{l}\mathrm{r} \\
++\end{array}$ \\
\hline
\end{tabular}

固型飼料（マウス繁殖用）をあたえ，約 $27^{\circ} \mathrm{C}$ の室温で 保存したところ，第 1 回の産子からこの状態で第 2 回の 産子をしたものは 6 尾で，その間隔はそれぞれ 10 日， 21 日，25日，30日，42 日，45日（平均 28.8 日）, その うちさらに第 3 回の産子をしたものは 3 尾で，その間隔 は3 33 日，39日，41日（平均 37.7 日），さらにそのうち
の 1 尾は 31 日後に第 4 回の産子を扢こなった。 カダヤシに関しては，自然界ではさらに短い間隔で多 くの子をうむと推定されるが,この観察でも水温が $27^{\circ} \mathrm{C}$ 前後である限り年間を通じて長くとも捛よそ1か月の間 隔で産子をくりかえすむのと考えられる。

\section{2 蚊幼虫捕食数の観察}


表 9 カダヤシの体長と 1 回の産子数の関係

\begin{tabular}{|c|c|c|c|c|c|c|c|c|c|c|c|c|}
\hline $\begin{array}{l}\text { 産子数 } \\
\text { 体長 } \\
(\mathrm{mm})\end{array}$ & $\begin{array}{c}0 \\
1 \\
19\end{array}$ & $\begin{array}{c}20 \\
? \\
39\end{array}$ & $\begin{array}{c}40 \\
? \\
59\end{array}$ & $\begin{array}{c}60 \\
\imath \\
79\end{array}$ & $\begin{array}{c}80 \\
? \\
99\end{array}$ & $\begin{array}{c}100 \\
? \\
119\end{array}$ & $\begin{array}{c}120 \\
? \\
139\end{array}$ & $\begin{array}{c}140 \\
l \\
159\end{array}$ & $\begin{array}{c}160 \\
l \\
179\end{array}$ & $\begin{array}{l}180 \\
? \\
199\end{array}$ & $\begin{array}{l}200 \\
219\end{array}$ & Total \\
\hline 2.6 & 2 & 1 & & & & & & & & & & 3 \\
\hline 2.8 & & 1 & & & & & & & & & & 1 \\
\hline 3.0 & 1 & 1 & & & & & & & & & & 2 \\
\hline 3.2 & 1 & 5 & 3 & & & & & & & & & 9 \\
\hline 3.4 & & 2 & 6 & & & & & & & & & 8 \\
\hline 3.6 & & 3 & 4 & & & & & & & & & 7 \\
\hline 3.8 & & 1 & 3 & 4 & 2 & 1 & & & & & & 11 \\
\hline 4.0 & & 1 & 1 & 1 & & 1 & & & & & & 4 \\
\hline 4.2 & & & & 2 & 1 & 1 & 2 & & & & & 6 \\
\hline 4.4 & & & & 1 & & & & & & & & 1 \\
\hline 4.6 & & & & & & 1 & & 1 & & & 2 & 4 \\
\hline 4.8 & & & & & & & & & & 1 & & 1 \\
\hline 5.4 & & & & & & & & & & & 2 & 2 \\
\hline 計 & 4 & 15 & 17 & 8 & 3 & 4 & 2 & 1 & 0 & 1 & 4 & 59 \\
\hline
\end{tabular}
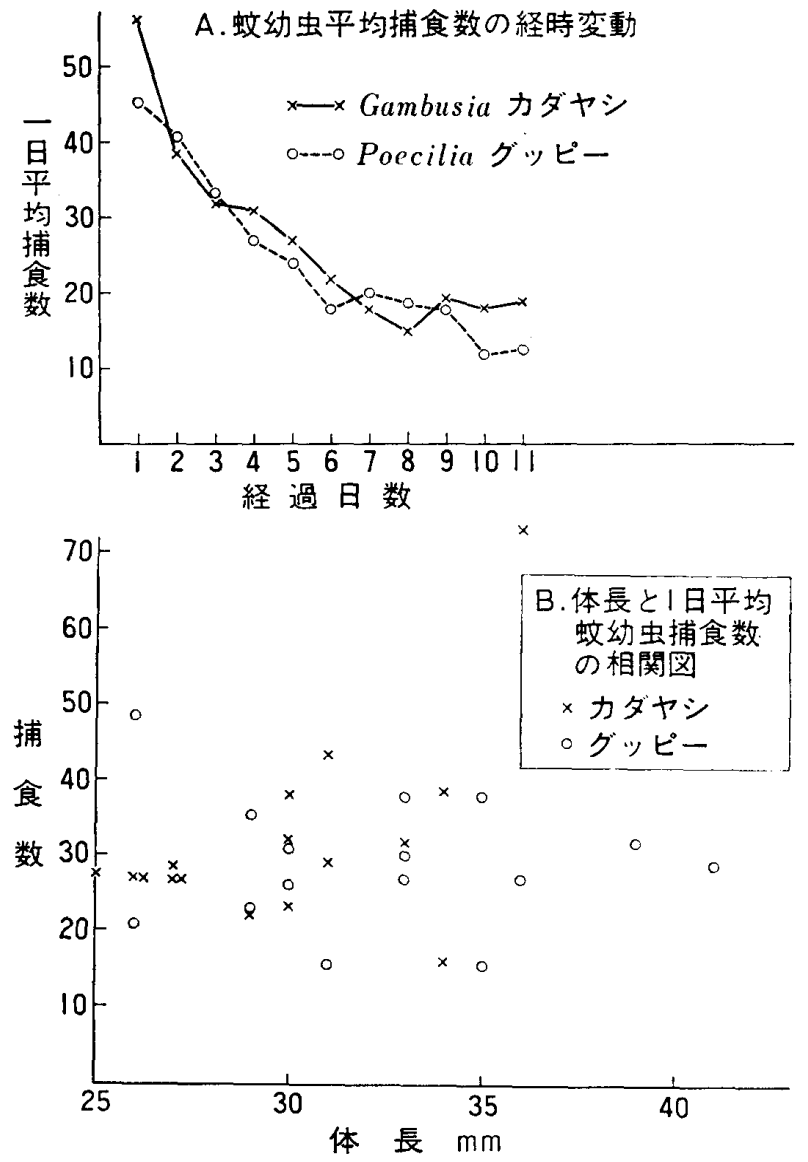

図 4 カダヤシとグッピーの蚊幼虫捕食実験成績

グッピーの蚊幼虫捕食能についてはすでに Yamagishi (1966)の報告もあるが，この方法にならい，カダヤシ， グッピーの両種について～ 15 尾ずつを個別に容器に入 れ, $25^{\circ} \mathrm{C}$ においてチカイェカ Culex pipiens molestus
4 令幼虫をあたえ，7日間（一部の魚については 11 日 間）にわたりその捕食数をしらべた，蚊幼虫は実験室内 で累代飼育した川崎系を用い，每日 50 匹ずつをあたえ， もしそれを食い尽した場合にはさらに50匹を追加する ことを原則とし，24 時間後に残存幼虫数を数え，これを 除去して新しく50 匹をあたえた。

その結果は表 10 と図 4 に示すように，1尾 1 日あたり の平均捕食数はカダヤシで最高 73.6 , 最少 16.0 , 平均

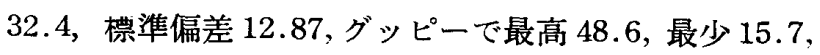
平均 29.4, 標淮偏差 7.83 とい5成績であった。 また, 体長と捕食数の相関をしらべると，カダヤシでは相関係 数 $r=0.5122, t=2.1503$ となり， $N=15$ ，したがって $t$ 分布表からはほぼ $5 \%$ 危険率で相関がないという仮 定が否定される。グッピーでは $\gamma=0.0541 ， t=-0.1951$ で，体長と捕食数の間には相関が認められない，それは 図 $4 \mathrm{~B}$ にも明らかである。

実験を開始してから毎日の蚊幼虫捕食数の平均をしら ベると，図 4 に示すようにカダヤシ，グッピーとも第 1 日の捕食数が最高で，それぞれ $58.3 ， 45.3$ を示し， そ の後次第に減少して第 5 日ころからほぼ20匹の水淮に落 着くといら傾向がみられた。

5.3 低温に対する耐性

1966 年から東京の医科研構内で野外に人工池を作り, カダヤシおよびグッピーを越冬させた観察では，グッピ 一は毎年 12 月中に水温が約 $10^{\circ} \mathrm{C}$ になると全隇したが, カダヤシは 1,2 月中に水面が氷結し, 水底温度が約 $4^{\circ} \mathrm{C}$ に泠却されても越冬して, 寸でに 5 年あまり同一の 池内棲息がつづいている，徳島市においても野外です 
表 10 グッビーおよびカダヤシのチカイエカ 4 令幼虫捕食数（個別，1 週間観察）

\begin{tabular}{|c|c|c|c|c|c|c|c|c|c|c|c|c|c|c|c|c|c|}
\hline & & Gupp & $: P$ & ecilli & ret & culat. & & & & & $\mathrm{Mi}$ & anow & $G a$ & nbust & ia affh & inis & \\
\hline & & Numb & er of & larva & & sume & d per & day & & & Jumb & er of & & & asume & ed per & day \\
\hline$(\mathrm{mm})$ & 1 & 2 & 3 & 4 & 5 & 6 & 7 & Average & & 1 & 2 & 3 & 4 & 5 & 6 & 7 & Average \\
\hline 41 & 43 & 50 & 50 & 28 & 16 & 15 & 4 & 29.4 & 36 & 200 & 42 & 67 & 66 & 89 & 18 & 33 & 73.6 \\
\hline 39 & 50 & 50 & 50 & 37 & 13 & 14 & 15 & 32.7 & 34 & 78 & 18 & 13 & 41 & 51 & 42 & 27 & 38.6 \\
\hline 36 & 69 & 47 & 22 & 8 & 13 & 22 & 11 & 27.4 & 34 & 27 & 30 & 13 & 0 & 14 & 15 & 13 & 16.0 \\
\hline 35 & 50 & 50 & 50 & 19 & 44 & 22 & 29 & 37.7 & 33 & 36 & 50 & 50 & 55 & 19 & 12 & 6 & 32.6 \\
\hline 35 & 74 & 6 & 8 & 28 & 21 & 5 & 13 & 22.1 & 31 & 50 & 50 & 50 & 73 & 17 & 39 & 27 & 43.7 \\
\hline 33 & 50 & 50 & 49 & 42 & 25 & 21 & 27 & 37.7 & 31 & 50 & 50 & 39 & 29 & 11 & 9 & 9 & 28.1 \\
\hline 33 & 29 & 50 & 12 & 16 & 41 & 39 & 24 & 30.1 & 30 & 98 & 50 & 24 & 24 & 32 & 16 & 21 & 37.9 \\
\hline 33 & 10 & 36 & 39 & 23 & 35 & 22 & 28 & 27.6 & 30 & 50 & 50 & 50 & 44 & 7 & 12 & 13 & 32.3 \\
\hline 31 & 7 & 28 & 20 & 12 & 12 & 15 & 16 & 15.7 & 30 & 50 & 26 & 29 & 24 & 12 & 6 & 17 & 23.4 \\
\hline 30 & 43 & 33 & 11 & 34 & 29 & 13 & 20 & 26.1 & 29 & 29 & 13 & 8 & 4 & 47 & 40 & 16 & 22.4 \\
\hline 30 & 50 & 50 & 38 & 23 & 13 & 30 & 14 & 31.1 & 27 & 50 & 50 & 33 & 15 & 11 & 28 & 12 & 28.4 \\
\hline 29 & 27 & 42 & 56 & 40 & 29 & 31 & 24 & 35.6 & 27 & 50 & 50 & 32 & 24 & 8 & 12 & 14 & 27.1 \\
\hline 29 & 50 & 50 & 25 & 14 & 15 & 3 & 8 & 23.6 & 26 & 15 & 44 & 15 & 28 & 27 & 38 & 23 & 27.1 \\
\hline 26 & 28 & 26 & 18 & 27 & 22 & 9 & 18 & 21.1 & 26 & 50 & 50 & 32 & 9 & 9 & 21 & 19 & 27.1 \\
\hline 26 & 100 & 42 & 53 & 52 & 31 & 12 & 50 & 48.6 & 25 & 42 & 7 & 24 & 29 & 49 & 25 & 18 & 27.7 \\
\hline Average & 45.3 & 40.6 & 00. & 20.0 & 20.0 & 20. & 20.1 & 29.8 & Average & 58.3 & & 31.9 & & & & 17.9 & 32.4 \\
\hline
\end{tabular}

でに冬を 3 回越して繁殖がつゔけられている.

実験的に低温にさらしてみても両種の差は歴然として いる．たとえば，佐藤ら（1970）がすでに報告したよう に， $1 l$ 入りメスシリンダーに $7 \sim 10$ 尾のカダヤシまた はグッピーを入れ，上から氷を徐々に加えて $20^{\circ} \mathrm{C}$ から 5 分ごとに $1^{\circ} \mathrm{C}$ の割合で温度を下げていくと， カダヤ シは $4^{\circ} \mathrm{C}$ までは健全で, $2.5^{\circ} \mathrm{C}$ で約半数が転倒する が，グッピーは $13^{\circ} \mathrm{C}$ から転倒がみられ， $10^{\circ} \mathrm{C}$ で約半 数が転倒し, $8^{\circ} \mathrm{C}$ で全部転倒することが 5 回のくりかえ しでいずれも同様の結果であった。

1972 年 2 月には，クールニクス（コマッ・ヤマト， CTR-120 型）を用い， $500 \mathrm{ml}$ のビーカー中に各種の魚 を放って $23^{\circ} \mathrm{C}$ から $3^{\circ} \mathrm{C}$ ま゙， 1 時間に $1^{\circ} \mathrm{C}$ ずつの 割で泠却する実験を 2 回行なった。 カダヤシ（（１0 尾） は 21 時間後, $3^{\circ} \mathrm{C}$ に抒いて 1 尾のみ転倒, メダカは 10 尾の全部が $3^{\circ} \mathrm{C}$ でも転倒しなかった。 グッピー（ㅇ 10 尾）は $11^{\circ} \mathrm{C}$ で 2 尾, $10^{\circ} \mathrm{C}$ で全部が転倒, ブラックモ ーリー 10 尾は $8^{\circ} \mathrm{C}$ までは転倒せず, $7^{\circ} \mathrm{C}$ で全部転 倒, セルフィンモーリー, ソードティル, プラティ, テ ラピアは各ㅇ 5 尾を用いたが， 2 回ともいずれも $11^{\circ} \mathrm{C}$ まで健全で $10^{\circ} \mathrm{C}$ で全部転倒, リミアは第 1 回は $8^{\circ} \mathrm{C}$ で, 第 2 回は $7^{\circ} \mathrm{C}$ で全部倒れた。 またアフリカ 原産の Notobranchius guntheri は最も低温に弱く, 7 9のう ち $17^{\circ} \mathrm{C}$ で 3 尾, $16^{\circ} \mathrm{C}$ で 4 尾, $15^{\circ} \mathrm{C}$ で 7 尾が転倒し た。

\section{3 遊離塩素のカダヤシに対する毒性}

カダヤシやグッピー（ニジメダカ）を水道水に放すと 死亡することが多く，それは遊離塩素の毒性にもとゔく ものと推定されるので，それらの飼育管理に必要な基礎 資料をうるため実験をおこなった。たとえば東京の水道

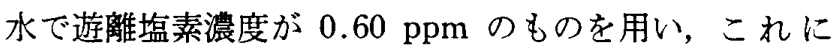
脱イオン水を加えて各段階に稀䣋したものを調製し，そ れぞれに 20 尾ずつの魚を放したところ，初濃度が 0.6 $\mathrm{ppm}$ の場合にはカダヤシは 3 時間, グッピーは 2 時間 で全部転倒（のち死亡）， $0.5 \mathrm{ppm}$ では両種とも 3 時間 で約半数が死亡したが残りは生存し， $0.45 \mathrm{ppm}$ ではグ ッピー4, カダヤシ 2 が，また $0.4 \mathrm{ppm}$ では グッピー 1 が 3 時間後に転倒したほか生存し， $0.3 \mathrm{ppm}$ では全部 生存した. すなわち，カダヤシ，グッピーともこれを飼 育するためには 遊離塩素量を $0.3 \mathrm{ppm}$ 以下にすること が必要と考えられる。

カダヤシは蚊幼虫の天敵として，とくにマラリアの予 防の目的で今世紀の初めころからョーロッパ，アジアの 多くの地域に移植され，その成績については多くの報告 がある(Gerberich and Laird 1966)。しかし，それに上 って実際にマラリアの予防に成果があったという事実は ほとんど知られていない，それは朽そらくカダヤシの䇣 殖に適する水域と, マラリア媒介蚊の発生水域とが多く 
の場合一致していないためであろう。たとえば東南アジ アのマラリア主要媒介蚊である Anopheles minimus, An. maculatus は主として山脚の 涌水や小川に, An. aconitus は水田に発生している.これに対し，カダヤシ はむしろ人家周辺の下水が流れこむ污水域によく繁殖 し，アカイエカの天敵として有効なものと考えられる.

徳島市へのカダヤシ移植は，はじめから都市周辺の污 水が流入する溝，池，湿地などに発生する蚊の駆除を目 的に行なわれたことは従来のマラリア予防という目標と 異なっている。 しかも，数十万の人口をもつ都市域でわ ずか 2 年のらちにこのように旺盛で広範な繁殖がみら れ，蚊の発生抑制に大きな成果を収めたという例は徳島 がはじめてであろう。 また，この地城の地理的環境がた ままたカダヤシの繁殖に適していたこともたしかで，こ の魚がどんな環境に扔いてもこうした成果をあげうると は考えられない。

徳島において数十へクタールにわたる湿地帯に放した カダヤシがおびただしく繁殖して，セスジヤブカを主体 とした蚊の毎年の大発生を予防したことは天敵による害 虫駆除の成功の一例として注目される。このような場 合，従来のような殺虫剂による駆除に比べて効果が永続 すること，労力と費用がいらないこと，環境污染がない ことなど，あらゆる面でこの生物学的方法がすぐれてい ることが示された。

しかし，このような天敵利用の方法があらゆる蚊幼虫 発生源に有効であるとは限らない，徳島市の場合にも， 水の乾きやすい所や，ごみの多い下水など，カダヤシの 効果がみられなかった場所もある。 また，カダヤシの導 入がメダカなどの在来生物を駆逐するという，外来生物 による自然界のバランスの破壊が今後どのような方向に すすむかについても監視をつゔける必要があるう。

\section{まとめ}

カダヤシは 1916 年に日本に 移入され，東京周辺の污 水だまりなどに繁殖しているが，これを蚊幼虫の天敵と して利用するため 1969 年 4 月に徳島市に移殖したとこ ろ，住宅地周辺の池，湿地，下水溝，廃田などにいちじ るしく繁殖し，それらに発生する蚊幼蟖除に大きな効 果を示した。

徳島市周辺についてライトトラップによる蚊幼虫の定 期捕集，幼虫発生源の調查などを 3 年余りにわたりつつ けた. この地域で拉よそ 16 種の蚊が採集され，それぞ れの季節消長や発生源などの生態を明らかにしたが，と くにアカイエカが広い水域におびただしく繁殖している こと，海岸の湿地带にセスジヤブカの多発していること が注目された。
移入したカダヤシは約 3 か所の池で一たん繁殖させた 後,さらに多数の蚊幼虫発生源に二次，三次の移殖を押 こなった。この魚がすみついた水域ではいずれも蚊幼虫 駆除効果がいちじるしく見られた．とくに海岸近くの数 十へクタールにわたる湿地帯に毎年周期的にセスジャブ カ, シナ八マダラカ，コガタアカイエカなどの大発生が あって住民の被害がいちじるしかったが，カダヤシ導入 の翌年から蚊の発生がまったくみられなくなった。

各水域に放したカダヤシについてその分布，棲息密度 の動向, 在来種のメダカとの競争関係, 蚊幼虫駆除効果 などの野外調査と，実験室内での産子数，産子間隔，低 温に対する耐性，蚊幼虫捕食能，遊離塩素などの毒物の 影響について観察を行なった。

本稿を終えるにあたり，多大なご援助を賜った徳嶌市 長武市一夫氏，同市保健衛生部の職員諸氏，蚊の採集運 搬にご協力いただき，ご助言をいただいた元徳島市保健 衛生部長佐野茂夫博士 (現德島県小松島保健所長)，終始 ご協力とご便宜を賜った徳島市医㑲会の諸氏，協力を賜 った大高正俊氏，種々ご教示をいただいた東京大学医科 学研究所寄生虫研究部の諸兄，そして徳島市のカダヤシ の種となった東京空港でのカダヤシの採集にご便宜㭛計 られ，ご協力をいただいた，東京空港検疫所衛生課長長 尾正巳博土，同検疫所引地德郎技官の各位に哚く感謝の 意を表します。

\section{参考文献}

Gerberich,J.B. and Laird, M. (1966) : An annoted bibliography of papers relating to control of mosquitoes by the use of fish (Revised and enlarged to 1965). WHO/EBL/66. 71 (mimeographed, 107 pp.)

伊藤嘉昭 (1963)：動物生態学入門一個体群生態学編。 $395 \mathrm{pp}$., 古今書院, 東京.

Mallars, J. L. and Fowler, J. R. (1970) : Mosquito eating fishes in California, $27 \mathrm{pp}$. California Mosquito Control Association, Visalia, California.

長沢佳熊, 越村栄之助, 福田秀男 (1968)：熱帯魚グッ ピーによるパラチオンおよびシアン化カリウムり定 量とパラチオンの $\mathrm{LD}_{50}$ およびシアン化カリウムの $\mathrm{ED}_{50}$. 衛生試験所報告, $86: 32-36$.

Nakagawa, P. Y. and Ikeda, J. (1969) : Biological control of mosquitoes with larvivorous fish in Hawaii. WHO/VBC/69. 173 (mimeographed, 25 pp.).

中村守純 (1941)：タップミンノウの飼育. 採集と飼育, $16: 186-7$.

岡田弥一郎 (1957)：マラリア蚊幼出の天敵としての魚 類(防蚊魚類)ことにトップミノウについて。環境衛 生, '57 (10) : 6-13. 
Rosen, D. E. and Bailey, R. M. (1963) : The poecilid fishes (Cyprinodontiformes), their structure, zoogeography, and systematics. Bull. Amcrican Museum of Natural History, 126, Article 1, $176 \mathrm{pp}$.

Sasa, M., et al.(1965) : Studies on mosquitoes and their natural enemies in Bangkok, Pt. 2. Insecticide susceptibility of the larvae of Culex pipiens fatigans, Aedes aegypti and the mosquito eating fish Lebistes reticulatus: $\mathrm{Pt}$. 3 . Observations on a mosquito eating fish "guppy", Lebistes reticulatus, breeding in polluted waters. Jap. J. Exp. Med., 35(1) : 51-80.

佐々学，ほか (1967)：鼠族昆虫駆除事業構造改善沪関 する研究レポート（その 3$)$ ：生物学的駆除，上: 淡水魚の利用による蚊幼虫駆除につい下。生活之環 境, 12(7) : 20-23.

佐々学 (1971)：生物を利用する環境衛生の改善，二， に胎生メダ力科淡水魚の利用について。学術月報, 23(10) : 601-606.

佳々学 (1972)：生物を利用する環境衛生の改善—之く に胎生メダ力科淡水魚の利用につい下一，文部少研 究報告集録 (昭 46, 人間生存々自然環境). 108-116. 估藤英毅, 和田芳武, 元木貢, 大久保新也 (1970)：德 島市に招ける蚊の研究. 衛生動物，21(2)：121-122.

估藤英毅, 和田芳武, 元木貢, 佳々学 (1970)：日本: 土着した Poeciliidae 科淡水魚の 2 種 Lebistes reticulatus (ニジメダカ) および Gambusia affinis(つ ダヤシ）の蚊沙虫天敵としての性質の比較. 衛生動 物, $\mathbf{2 1}(2): 125$.

佐藤英毅，大久保新也(1971)：徳島市に移入した力夕 ヤシ Gambusia affinis の繁殖状況上蚊幼虫駆除安 績について。衛生動物, 22(2)：90-91.

传藤英毅，大久保新也(1972)：德島に晾注る力ダてシ Gambusia affinis およびメダカ Oryzias latipes D 分布について。衛生動物, 22(4): 244.

山岸宏, 中村譲, 和田芳武, 沖野外輝夫, 中本信忠 (1966)： グッピーの生態学的研究 I. 日本の温泉地に沿いて 自然繁殖するグッピーについて。衛生動物，17(1): 48-58.

Yamagishi, H. (1966) : Ecological studies on the guppy, Lebistes reliculatus Peters. II. Experiments on predation of mosquito larvae by guppies. J. Faculty of Science, Shinshu Univ., 1 : 79-92.

山岸宏, 沖野外輝夫, 中本信忠, 中村讓, 和田芳武 (1967)： グッピーの生態学的研究 III. 戸倉・上山田温泉り晹 尻に環境順化したグッピー個体群について、日本殅 態学雑誌, $17(5): 206-213$.

\section{Summary}

The top minnow, Gambusia affinis Baird et Girard, 1853), is a viviporous poeciliid fish native of the southern United States, and has been introduced into a number of countries mainly with the purpose of malaria control. In Japan, the fish is known to be imported in 1916 via Hawaii and Taiwan, and has been found recently to be breeding widely in polluted waters in and around the city of Tokyo. The present paper deals with the results of observations on Gambusia introduced from Tokyo to Tokushima City of Shikoku Island in April 1969.

Tokushima is a city situated on the delta of Yoshino River, where tremendous numbers of mosquitoes were breeding every year in swamps, ditches and rice paddies difficult to be drained. Surreys were carried out on the larval breeding places, and on the seasonal prevalence of adults with light traps set at 6 stations. Of 14 species of mosquitoes found in this area, Culex pipiens pallens was predominant and most widely distributed, while Anopheles sinensis and Culex tritaeniorhynchus were also found abundantly in some swamp areas. In some salt marshes near the sea coast, tremendous breeding of Aedes dorsalis was observed in the rainy seasons.

Under such environmental conditions, it was considered by us that the introduction of $\mathrm{Gam}$ busia might be an effective measure for the control of mosquitoes, and two shipments of about 400 fishes collected from sewage ditches in the Tokyo International Airport were made to Tokushima by air cargo in April and May, 1969. The fishes were released and bred first in certain ponds and pools, and were further distributed to other ponds, swamps and ditches from the autumn of 1969. Especially successful and effective was the culture of Gambusia in the salt water marshes where Aedes dorsalis had been breeding; from August 1970, one year after the first batch of some 500 fishes were released, they became visible in high population densities all over the swamps, and thereafter complete eradication of the mosquito larvae could be achieved from these areas.

Field and laboratory studies were made with Gambusia thus successfully established in large number of pools in and around this city. The results are described in this report on its distribution, the trend of increase in the population densities, the competition with the indigenous fishes such as Oryzias latipes, the capacity as a predator of mosquito larvae, the correlation of the number of youngs borne with the body size of the mother fishes, the intervals of the births, the resistance to the cold temperature and to various poisonous substances in water, etc. 